\title{
Uji Kandungan Senyawa Metabolit Sekunder pada Ekstrak Daun Jambu Biji (Psidium guajava L. var. Pomifera) dari Kota Langsa, Aceh
}

\author{
Reni Aisyah Simbolon ${ }^{1}$, Halimatussakdiah ${ }^{1 *}$, dan Ulil Amna ${ }^{1}$ \\ ${ }^{1}$ Program Studi Kimia Fakultas Teknik Universitas Samudra \\ J. Meurandeh, Langsa Aceh 24416, Indonesia \\ *Corresponding author: halimatussakdiah@unsam.ac.id
}

\begin{abstract}
ABSTRAK
Tumbuhan jambu biji (Psidium guajava L.) merupakan salah satu tanaman obat-obatan yang sering dimanfaatkan oleh masyarakat khususnya di Indonesia. Tumbuhan yang termasuk ke dalam famili Myrtaceae tersebut memiliki khasiat sebagai antidiare, antioksidan, antiinflamasi, dan antimikroba. Penelitian ini bertujuan untuk mengetahui kandungan senyawa metabolit sekunder yang terdapat dalam daun jambu biji merah (Psidium guajava L. var. Pomifera). Berdasarkan pengujian fitokimia yang telah dilakukan, menunjukkan bahwa daun kering positif mengandung senyawa steroid, saponin, fenol, dan tanin. Sedangkan pada daun segar positif mengandung senyawa alkaloid, steroid, saponin, fenol, dan tanin.
\end{abstract}

Kata Kunci: Jambu Biji, Kota Langsa, Metabolit Sekunder, Psidium guajava L.

\section{PENDAHULUAN}

Pengetahuan tentang tanaman obat telah diketahui secara turun temurun dari generasi ke generasi berdasarkan pengalaman masyarakat yang juga merupakan warisan budaya bangsa. Salah satu tanaman yang berkhasiat sebagai obat adalah tanaman jambu biji [1]. Nama daerah untuk tanaman jambu biji diantaranya adalah Glima breueh (Aceh), galiman (Sumatera), jambu klutuk (Jawa), jambu batu (Sunda), Jambu bender (Madura), gojawas (Manado), libu (Kalimantan), kojabas (Nusa Tenggara) dan kayawese (Maluku) [2]. Tumbuhan jambu biji termasuk ke dalam famili Myrtaceae [3].

Klasifikasi tanaman jambu biji meliputi :

$\begin{array}{ll}\text { Divisi } & \text { : Spermatophyta } \\ \text { Subdivisi } & \text { : Angiospermae } \\ \text { Kelas } & \text { : Dicotyledonae } \\ \text { Bangsa } & \text { : Myrtales } \\ \text { Suku } & \text { : Myrtaceae } \\ \text { Marga } & \text { : Psidium } \\ \text { Jenis } & \text { : Psidium guajava L. [4] }\end{array}$

Tumbuhan ini juga dikenal sebagai buah apel tropis [5]. Ada dua jenis varietas jambu biji, yaitu jambu biji berdaging putih (Psidium guajava var. Pyrifera) dan jambu biji berdaging merah (Psidium guajava var. Pomifera) [6]. Jambu biji merah mempunyai banyak manfaat dalam dunia medis, agroindustri, serta sebagai bahan manufaktur lainnya [7]. Jambu biji merah merupakan jenis tanaman tropis yang telah dibudidayakan secara luas, dan mempunyai kandungan gizi yang tinggi [8].

Jambu biji memiliki kandungan nutrisi yang yang cukup lengkap terutama kadar vitamin $\mathrm{C}$ yang cukup tinggi, serta mempunyai cita rasa yang menyenangkan [9], [10]. Jambu biji merah dapat diolah dalam bentuk jus, sari buah dan juga dikonsumsi dalam bentuk segar [11].

Beberapa penelitian telah membuktikan bahwa jambu biji mempunyai khasiat sebagai antisariawan, meningkatkan penglihatan, mengobati sembelit perut, antidiare, antiinflamasi, antioksidan, pengobatan sakit maag, keputihan, diabetes, antibakteri dan sebagai antikanker, meningkatkan kadar trombosit darah, menurunkan kadar kolestrol, serta menurunkan kadar gula darah [3], [5], [12][14]. Semua bioaktivitas tersebut dikontribusikan oleh kandungan senyawa metabolit sekunder.

Metabolit sekunder merupakan suatu produk alami yang diturunkan dan disintesa dari metabolit primer tumbuhan seperti karbohidrat, asam amino dan lipid. Berdasarkan struktur kimianya, metabolit sekunder dibedakan atas 
alkaloid, terpenoid, dan senyawa fenolik [15]. Beberapa penelitian menunjukkan bahwa jambu biji merah memiliki kandungan senyawa metabolit sekunder seperti steroid, saponin, flavonoid, fenol, dan tanin, sehingga memiliki aktivitas sebagai antimikroba dan antibakteri [5], [12], [13], [16]. Suatu penelitian menunjukkan bahwa ekstrak daun jambu biji memiliki senyawa antibiotik dan dapat menghambat pertumbuhan bakteri pathogen usus halus (Escherichia coli) yang menginfeksi ayam [17].

\section{METODE PENELITIAN}

\section{Bahan}

Bahan yang digunakan dalam penelitian ini adalah daun jambu biji merah kering, daun jambu biji merah segar, etanol, metanol, $n$ heksana, Mg, pereaksi Liberman-Bourchard, pereaksi Meyer, pereaksi Dragendorf, Wagner, ammonia, kloroform, $\mathrm{H}_{2} \mathrm{SO}_{4} 2 \mathrm{~N}, \mathrm{HCl}$ pekat, $\mathrm{FeCl}_{3} 0,1 \%$, kertas saring, dan kertas label.

\section{Alat}

Peralatan yang digunakan dalam penelitian ini meliputi cawan porselin, tabung reaksi dan raknya, erlenmeyer, pipet tetes, spatula, hot plate, dan corong pisah.

\section{Metode}

\section{a. Pengambilan Sampel}

Daun tanaman jambu biji ( $P$. guajava L. var. Pomifera) diambil di Gampong Meurandeh, Dusun Bahagia II, Kecamatan Langsa Lama, Kota Langsa, Aceh. Daun terlebih dahulu dikeringanginkan dengan cara menjemur sampel tanpa bantuan sinar matahari, agar senyawa yang terkandung dalam sampel tidak rusak, selanjutnya dihaluskan hingga diperoleh serbuk kering yang akan diekstraksi.

\section{b. Ekstraksi}

Daun segar dan daun kering ( $P$. guajava L. var. Pomifera) diekstraksi dengan metanol. Larutan ekstrak disaring dan diuapkan dengan rotary evaporator untuk menghasilkan ekstrak metanol [18].

\section{c. Uji alkaloid}

Ekstrak sampel diambil sedikit dan ditambahkan $1 \mathrm{~mL}$ amonia. Selanjutnya ditambahkan $10 \mathrm{~mL}$ etil asetat, kemudian disaring. Filtrat ditambahkan $10 \mathrm{~mL}$ asam sulfat $2 \mathrm{~N}$, dikocok kuat-kuat, dibiarkan selama satu menit sampai larutan asam sulfat dan etil asetat terpisah. Lapisan asam sulfat diambil dan dibagi menjadi tiga tabung reaksi dan setiap tabung reaksi diuji dengan pereaksi Meyer, Dragendorff, dan Wagner untuk menentukan keberadaan alkaloid. Penambahan reagen Meyer membentuk endapan putih, reagen Dragendorff menyebabkan endapan kemerahan, dan reagen Wagner membentuk endapan kuning. Hasil tersebut menunjukkan adanya kandungan senyawa alkaloid [18].

\section{d. Uji Terpenoid, Steroid, dan Saponin}

Ekstrak metanol dipartisi dengan $n$-heksana. Ekstrak larut dalam $n$-heksana diuji dengan reagen Liberman-Bourchard. Warna biru atau hijau menunjukkan adanya steroid dan warna merah untuk terpenoid. Residu yang tidak larut dalam $n$-heksana ditambahkan air dan diguncang dengan kuat. Apabila ada busa stabil selama 30 menit menunjukkan adanya saponin, jika positif untuk saponin, larutan kemudian dihidrolisis dengan $\mathrm{HCl}$ dan diuji dengan pereaksi Liberman-Bourchard. Warna hijau atau biru menunjukkan adanya saponin steroid dan warna ungu atau merah menunjukkan adanya saponin terpenoid [18].

\section{e. Uji Flavonoid}

Ekstrak metanol pekat dipartisi dengan $n$ heksana. Residu diekstraksi dengan $10 \mathrm{~mL}$ etanol $80 \%$, kemudian ditambahkan $0,5 \mathrm{mg}$ magnesium dan $\mathrm{HCl} 0,5 \mathrm{M}$. Warna merah muda atau ungu menunjukkan adanya flavonoid [18].

\section{f. Uji Fenol}

Ekstrak metanol diuji dengan $\mathrm{FeCl}_{3}$. Ditambahkan 3 - 4 tetes larutan $\mathrm{FeCl}_{3}$ ke dalam ekstrak yang sebelumnya telah ditambahkan sedikit pelarut metanol, pembentukan warna hitam kebiruan menunjukkan senyawa adanya fenol [18] 


\section{g. Uji Tanin}

Sebanyak $1 \mathrm{~g}$ ekstrak metanol direbus dalam 10 $\mathrm{mL}$ air dalam tabung reaksi dan kemudian disaring. Filtrat ditambahkan beberapa tetes $\mathrm{FeCl}_{3} \quad 0,1 \%$. Pembentukan warna hijau kecoklatan atau hitam kebiruan menunjukkan adanya tanin [18].

\section{HASIL DAN PEMBAHASAN}

Dalam penelitian ini, sampel daun jambu biji diekstraksi dengan metode maserasi. Selanjutnya dilakukan analisis kandungan senyawa (uji fitokimia) yang terkandung dalam sampel meliputi uji alkaloid, terpenoid, steroid, saponin, flavonoid, fenol, dan tanin. Hasil uji fitokimia dapat dilihat pada Tabel 1 .

Tabel 1. Uji fitokimia daun jambu biji ( $P$. guajava L. var. Pomifera)

\begin{tabular}{clcc}
\hline No. & $\begin{array}{l}\text { Metabolit } \\
\text { Sekunder }\end{array}$ & $\begin{array}{c}\text { Daun } \\
\text { Kering }\end{array}$ & $\begin{array}{c}\text { Daun } \\
\text { Segar }\end{array}$ \\
\hline & Alkaloid & & \\
1. & - Dragendorff & $x$ & $x$ \\
& - Meyer & $x$ & $x$ \\
& - Wagner & $x$ & $\checkmark$ \\
2. & Terpenoid & $x$ & $x$ \\
3. & Steroid & $\checkmark$ & $\checkmark$ \\
4. & Saponin & $\checkmark$ & $\checkmark$ \\
5. & Flavonoid & $x$ & $x$ \\
6. & Fenol & $\checkmark$ & $\checkmark$ \\
7. & Tanin & $\checkmark$ & $\checkmark$ \\
\hline
\end{tabular}

Berdasarkan pengujian fitokimia yang telah dilakukan, menunjukkan bahwa daun kering positif mengandung senyawa steroid, saponin, fenol dan tanin. Sedangkan pada daun segar positif mengandung senyawa alkaloid, steroid, fenol dan tanin.

\section{a. Uji Alkaloid}

Pengujian kandungan alkaloid pada ekstrak daun segar jambu biji ( $P$. guajava $L$. var. Pomifera) secara kualitatif menunjukkan hasil positif terhadap keberadaan alkaloid, sedangkan ekstrak daun kering menunjukkan hasil negatif. Hal ini dapat disebabkan oleh kadar air yang tinggal sedikit pada sampel mengganggu reaksi sampel dengan reagen sehingga tidak terdeteksi.
Pada pengujian alkaloid ini menunjukkan hasil positif pada reagen Wagner yang ditandai dengan terbentuknya endapan berwarna kuning.

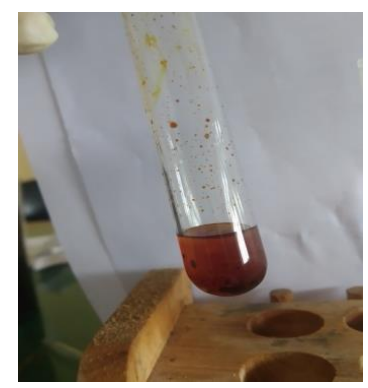

Gambar 1. Uji alkaloid daun jambu biji segar pada pereaksi wagner (positif alkaloid)

Alkaloid merupakan senyawa metabolit sekunder yang memiliki atom nitrogen terbanyak. Senyawa alkaloid sering ditemukan pada jaringan tumbuhan dan hewan. Sebagian besar senyawa alkaloid berasal dari tumbuh-tumbuhan. Alkaloid bersifat basa, sehingga dapat mengganti basa mineral dalam mempertahankan kesetimbangan ion dalam tumbuhan. Alkaloid pada tanaman berfungsi sebagai racun yang dapat melindunginya dari herbivora dan serangga, faktor pengatur pertumbuhan, dan senyawa simpanan yang mampu menyuplai nitrogen dan unsur-unsur lain yang diperlukan tanaman. Pada umumnya alkaloid ditemukan dalam kadar yang kecil, untuk menghasilkan alkaloid harus dipisahkan dari campuran senyawa yang berasal dari jaringan tumbuhan [19].

\section{b. Uji Terpenoid}

Pada pengujian kandungan terpenoid pada ekstrak daun segar dan daun kering jambu biji (P. guajava L. var. Pomifera) menunjukkan hasil yang negatif.

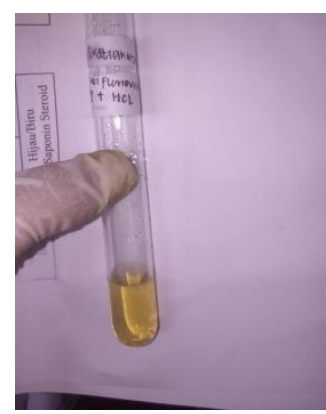

Gambar 2. Uji terpenoid daun jambu biji segar (negatif terpenoid) 
Terpenoid merupakan kelas metabolit sekunder yang tersusun oleh unit isopren yang berkarbon 5 (-C5) yang disintesa dari asetat melalui jalur asam mevalonik. Terpenoid memiliki struktur beragam yang dapat berupa molekul linear, hingga polisiklik, dengan ukuran dari himerterpen berunit lima karbon hingga karet yang memiliki ribuan unit isoprene [15].

\section{c. Uji Steroid}

Ekstrak daun segar dan daun kering jambu biji positif mengandung senyawa steroid yang ditunjukkan dengan terbentuknya warna hijau. Steroid merupakan terpenoid lipid yang dikenal dengan empat cincin kerangka dasar yang menyatu. Berdasarkan sumbernya, steroid dibedakan atas steroid sintesis dan alami. Steroid berperan penting bagi tubuh dalam menjaga keseimbangan garam, mengendalikan metabolisme dan meningkatkan fungsi organ seksual [20].

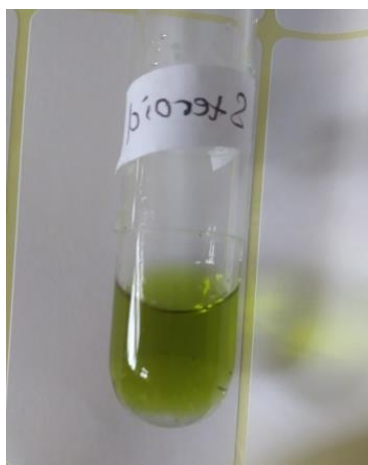

Gambar 3. Uji steroid pada daun jambu biji (positif steroid)

\section{d. Uji Saponin}

Pengujian kandungan senyawa saponin pada ekstrak daun segar dan daun kering jambu biji ( $P$. guajava L. var. Pomifera) menunjukkan hasil positif dimana terbentuk busa stabil selama 30 menit yang merupakan ciri keberadaan saponin [18].

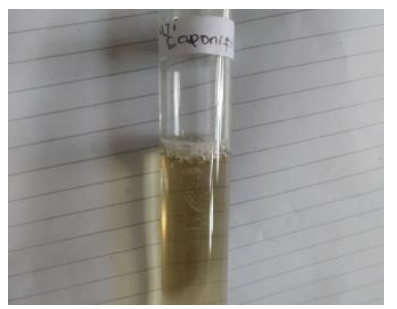

Gambar 4. Uji saponin pada daun jambu biji (positif saponin)
Uji saponin dapat dinyatakan positif dengan adanya rasa pahit, pembentukan busa yang stabil pada larutan cair dan mampu membentuk molekul dengan kolesterol [21]. Saponin adalah senyawa yang bersifat polar sehingga di maserasi menggunakan pelarut metanol. Reaksi uji busa merupakan sifat senyawa saponin yang mudah larut alam air dan akan menimbulkan busa ketika dikocok. Fungsi air adalah sebagai pelarut, sedangkan $\mathrm{HCl}$ berfungsi sebagai pereaksi. Gugus hidrofob bertindak sebagai permukaan aktif dalam pembentukan busa kemudian busa yang dihasilkan diuji kestabilannya dalam penambahan $\mathrm{HCl}$ [22].

Saponin merupakan glikosida yang memiliki aglikon berupa steroid dan triterpenoid. Saponin memiliki berbagai kelompok glikosil yang terikat pada posisi $\mathrm{C}_{3}$, tetapi beberapa saponin memiliki dua rantai gula yang menempel pada posisi $\mathrm{C}_{3}$ dan $\mathrm{C}_{17}$. Sruktur saponin tersebut yang menyebabkan saponin bersifat seperti sabun atau detergen sehingga saponin disebut sebagai surfaktan alami. Selain itu, saponin memiliki sifat kimia yang mudah larut dalam air. Saponin steroid tersusun atas inti steroid dengan molekul karbohidrat dan jika terhidrolisis akan menghasilkan aglikon atau dikenal dengan saraponin. Saponin steroid banyak ditemukan tumbuhan dikotil. Saponin triterpenoid tersusun dari inti triterpenoid dengan senyawa karbohidrat yang kemudian dihidrolisis sehingga menghasilkan agliko atau yang dikenal dengan sapogenin. Saponin triterpenoid banyak ditemukan pada tumbuhan monokotil. Jika dilihat dari fungsinya saponin berperan sebagai anti bakteri, anti moluska, anti virus, sitotoksik atau anti kanker [23], [24].

\section{e. Uji Flavonoid}

Berdasarkan uji kandungan flavonoid pada ekstrak daun segar dan daun kering jambu biji ( $P$. guajava L. var. Pomifera) menunjukkan hasil negatif. Namun, beberapa penelitian sebelumnya melaporkan bahwa daun jambu biji positif mengandung senyawa flavonoid [5], [12], [13]. Hal ini dapat dipengaruhi oleh unsur hara dalam tanah. 


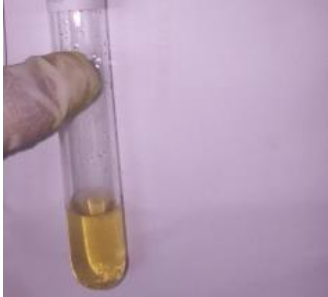

Gambar 5. Uji flavonoid daun jambu biji (negatif flavonoid).

Flavonoid merupakan senyawa polar, yang umumnya larut dalam pelarut polar seperti aseton, etanol, metanol, butanol, dimetil sulfoksida, dimetil formamida, air dan lain sebagainya. Flavonoid merupakan senyawa fenolik yang banyak terkandung pada jaringan tanaman. Flavonoid terdapat pada semua semua bagian tanaman meliputi daun, akar, kayu, kulit, tepung sari, nektar, bumga, daun buni dan biji. Penyebaran jenis flavonoid terbesar, yaitu pada angiospermae. Flavonoid merupakan salah satu kelompok antioksidan alami yang terdapat pada sereal, sayur-sayuran dan buah [25]. Flavonoid mempunyai kemampuan sebagai penangkap radikal bebas dan menghambat oksidasi lipid [26].

\section{f. Uji Fenol}

Pengujian kandungan senyawa fenol pada ekstrak daun segar dan daun kering jambu biji (P. guajava L. var. Pomifera) menunjukkan hasil positif terhadap keberadaan fenol. Keberadaan fenol ditandai dengan terbentuknya warna hitam kebiruan [18].

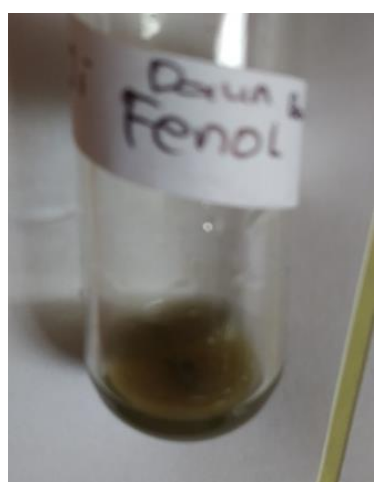

Gambar 6. Uji fenol pada daun jambu biji (positif fenol)

Senyawa fenol merupakan salah satu senyawa metabolit sekunder yang terjadi karena kondisi lingkungan yang tidak mendukung seperti cahaya yang kuat, suhu rendah, infeksi penyakit dan hama, serta kekurangan nutrisi. Senyawa fenol mudah larut dalam pelarut polar sehingga adanya gugus polar pada etanol menyebabkan banyak senyawa fenol ikut terlarut di dalam ekstrak [27]. Senyawa fenol dapat berfungsi untuk melindungi daun dari pancaran sinar UV-B dan kematian pada sel serta untuk melindungi DNA dari dimerisasi dan kerusakan [28].

\section{g. Uji Tanin}

Berdasarkan uji kandungan tanin menunjukkan bahwa ekstrak daun segar dan daun kering jambu biji ( $P$. guajava L. var. Pomifera) positif mengandung senyawa tanin. Keberadaan tanin ditandai dengan terbentuknya warna hijau kecoklatan pada uji tanin [18].

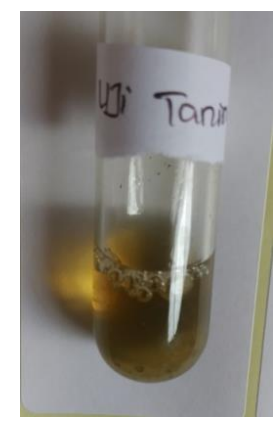

Gambar 7. Uji tanin pada daun jambu biji (positif tanin)

Tanin merupakan zat organik kompleks dan terdiri dari senyawa fenolik yang banyak terdapat pada bermacam-macam tumbuhan. Umumnya tanin tersebar hampir pada seluruh bagian tumbuhan seperti pada bagian kulit, kayu, batang, daun dan buah. Tanin adalah senyawa aktif metabolit sekunder yang diketahui mempunyai beberapa khasiat diantaranya yaitu sebagai astringent, antidiare, antibakteri dan antioksidan. Tanin berbentuk serpihan mengkilat berwarna kekuningan sampai coklat muda atau serbuk amorf, tidak berbau atau sedikit berbau khas. Tanin sangat mudah larut dalam air, alkohol, aseton, 1:1 dalam gliserol hangat, dan praktis tidak larut dalam petroleum, kloroform dan eter [29].

\section{KESIMPULAN}

Berdasarkan pengujian fitokimia yang telah dilakukan, dapat disimpulkan bahwa segar $P$. guajava L. var. Pomifera positif mengandung 
senyawa alkaloid, steroid, saponin, fenol, dan tanin. Sedangkan pada daun kering positif mengandung senyawa steroid, saponin, fenol, dan tanin.

\section{REFERENSI}

[1] S. S. H. Aponno V. J., Yamlean Y. V. P., "Uji Efektivitas Sediaan Gel Ekstrak Etanol Daun Jambu Biji (Psidium guajava Linn) terhadap Penyembuhan Luka yang Terinfeksi Bakteri Staphylococcus Aureus pada Kelinci (Orytolagus cuniculus)," PHARMACON, vol. 3, no. 3, pp. 279-286, 2014, doi: 10.35799/pha.3.2014.5400.

[2] R. Rachmaniar, H. Kartamihardja, and Merry, "Pemanfaatan Buah Jambu Biji Merah (Psidium guajava Linn.) Sebagai Antioksidan Dalam Bentuk Granul Effervescent," JSTFI Indones. J. Pharm. Sci. Technol., vol. 1, no. 5, pp. 1-20, 2016.

[3] Z. S. Desiyana S. L., Husni A. M., "Uji Efektivitas Sedian Gel Fraksi Etil Asetat Daun Jambu Biji (Psidium Guajava Linn) terhadap Penyenmbuhan Luka Terbuka pada Mencit (Mus musculus).," J. Nat., vol. 16, no. 2, pp. 23-32, 2016.

[4] Rabbiyah F., "Pengaruh Pemberian Ekstrak Daun Jambu Biji (Psidium guajava Linn.) terhadap Pengikatan Trombosit pada Pasien Demam Berdarah Dengue," J. Major., vol. 4, no. 7, pp. 9196, 2015.

[5] T. Handayani, Witjaksono, and K. U. Nugraheni, "Induksi Tetraploid Pada Tanaman Jambu Biji Merah (Psidium guajava L.) secara In Vitro," J. Biol. Indones., vol. 13, no. 2, pp. 271-278, 2017, doi: 10.47349/jbi/13022017/271.

[6] Y. Tampubolon R. T., "Pengaruh Formulasi Terhadap Sifat Fisik, Kimia, dan Organoleptik Effervescent Jambu Biji Merah (Psidium guajava var. Pomifera).," J. Pangan dan Agroindustri, vol. 5, no. 3, pp. 27-37, 2017.

[7] S. A. Ariyani A. M. D., Santoso I. S., "Analisa Profitalitas Usaha Tani Jambu Biji Getas Merah di Kabupaten Kendal," Acromedia, vol. 35, no. 2, pp. 10-18, 2017.

[8] I. S. W. Atmaja, Ismail Saleh, R. Eviyati, and D. Budirokhman, "Kajian Aplikasi Pupuk Kandang dan Pupuk Npk Terhadap Kualitas dan Mutu Jambu Biji Merah (Psidium guajava L.) Kultivar Getas pada Musim Kemarau," J. Agrovigor, vol. 9, no. 2, pp. 111-117, 2016.

[9] C. Dhyan, S. H. Sumarlan, and B. Susilo, "Pengaruh Pelapisan Lilin Lebah dan Suhu Penyimpanan Terhadap Kualitas Buah Jambu Biji (Psidium Guajava L.)," J. Bioproses Komod. Trop., vol. 2, no. 1, pp. 79-90, 2014.

[10] W. N. Gunawan R., Susanto H. W., "Pengaruh Lama Pemanasan dan Konsentrasi Maizena terhadap Karakteristik Fisik, Kimia dan Organoleptik Lempok Jambu Biji Merah (Psidium Guajava L.)," J. Pangan dan Agroindustri, vol. 6, no. 1, pp. 1-11, 2018

[11] D. N. Maria and E. Zubaidah, "Pembuatan Velva Jambu Biji Merah Probiotik (Lactobacillus Acidophilus) Kajian Persentase Penambahan Sukrosa dan CMC," J. Pangan dan Agroindustri, vol. 2, no. 4, pp. 18-28, 2014.

[12] W. R. Andriani, "Efektivitas Mengkonsumsi Jus Apel Dibandingkan dengan Mengkonsumsi Jus Jambu Biji terhadap Penurunan Tingkat Halitosis," AcTion Aceh Nutr. J., vol. 3, no. 2, pp. 164-171, 2018.

[13] F. Nadifah, S. Fatimah, and L. Susanti, "Pengaruh Infusa Daun Jambu Biji (Psidium guajava Linn.) Terhadap Pertumbuhan Bakteri Escherichia coli Secara In Vitro," J. Heal., vol. 2, no. 2, pp 65-68, 2015, doi: 10.30590/vol2-no2p65-68.

[14] I. B. Wicaksono and M. Ulfah, "Uji Aktivitas Antioksidan Kombinasi Ekstrak Etanol Daun Sirsak (Annona muricata L.) dan Daun Jambu Biji (Psidium guajava L.) dengan Metode DPPH (2,2-difenil-1pikrihidrazil)," Inov. Tek. Kim., vol. 2, no. 1, pp. 44-48, 2017.

[15] I. Hartati, S. Nurfaizin, Suwardiyono, and L. Kurniasari, "Ekstraksi Gelombang Mikro Terpenoid Daun Surian (Toona sureni Merr)," Inov. Tek. Kim., vol. 1, no. 2, pp. 98-103, 2016.

[16] A. U. Mulyanto S., Sumardianto, 
"Pengaruh Penambahan Ekstrak Daun Jambu Biji Merah (Psidium guajava) terhadap Daya Simpan Ikan Nila Merah (Oreochromis niloticus) pada Suhu Dingin," J. Pengolah. dan Bioteknol. Has. Perikan., vol. 6, no. 4, pp. 1-7, 2018.

[17] H. Setiawan, L. B. Utami, and M. Zulfikar, "Serbuk Daun Jambu Biji Memperbaiki Performans Pertumbuhan dan Morfologi Duodenum Ayam Jawa Super," J. Vet., vol. 19, no. 4, pp. 554-562, 2018.

[18] H. Halimatussakdiah, U. Amna, and P. Wahyuningsih, "Preliminary Phytochemical Analysis and Larvicidal Activity of Edible Fern (Diplazium esculentum (Retz.) Sw.) Extract against Culex," J. Nat., vol. 18, no. 3, pp. 141146, 2018, doi: 10.24815/jn.v0i0.11335.

[19] R. Ningrum, E. Purwanti, and Sukarsono, "Identifikasi Senyawa Alkaloid dari Batang Karamunting (Rhodomyrtus tomentosa) Sebagai Bahan Ajar Biologi Untuk SMA Kelas X," J. Pendidik. Biol. Indinesia, vol. 2, no. 3, pp. 231-236, 2016.

[20] A. R. Nasrudin., Wahyono., Mustofa., Saridarti, "Isolasi Senyawa dari Kulit Akar Sengugun (Elerdenrum serratum $L$. Moon)," J. Ilm. Farm., vol. 6, no. 3, pp. 332-337, 2017.

[21] N. Hidayah, "Pemanfaatan Senyawa Metabolit Sekunder Tanaman (Tanin dan Saponin) dalam Mengurangi Emisi Metan Ternak Ruminansia," J. Sain Peternak. Indones., vol. 1, no. 2, pp. 89-98, 2016, doi: 10.31186/jspi.id.11.2.89-98.

[22] Z. D. Novitasari, E. A. dan Putri, "Isolasi dan Identifikasi Saponin Saponin Pada Ekstrak Daun Mahkota Dewa Dengan Metode Maserasi," J. Sains, vol. 6, no. 12, pp. 10-13, 2016.

[23] B. Bintoro, A., Ibrahim, M.A., Situmeang, "Analisis Dan Identifikasi Senyawa Saponin dari Daun Sidara (Zhizipus Mauritania L.)," J. Itekimia, vol. 29, no. 1, pp. 84-93, 2017.

[24] . Y., H. Purnamaningsih, A. Nururrozi, and S. Indarjulianto, "Saponin: Dampak terhadap Ternak (Ulasan)," J. Peternak. Sriwij., vol. 6, no. 2, pp. 79-90, 2017, doi: 10.33230/jps.6.2.2017.5083.
[25] K. B. Yulianingtyas A., "Optimasi Volume Pelarut Waktu Maserasi Pengambilan Flavonoid Daun Belimbing Wuluh (Averhoa bilimbi L.)," J. Tek. Kim., vol. 10, no. 2, pp. 58-64, 2016.

[26] Z. Zuraida, S. Sulistiyani, D. Sajuthi, and I. H. Suparto, "Fenol, Flavonoid, dan Aktivitas Antioksidan pada Ekstrak Kulit Batang Pulai (Alstonia scholaris R.Br)," J. Penelit. Has. Hutan, vol. 35, no. 3, pp. 211-219, 2017, doi: 10.20886/jphh.2017.35.3.211-219.

[27] R. F. Anggraini and S. B. Widjanarko, "Pengaruh Penambahan Ekstrak Bekatul terhadap Aktivitas Antioksidan, Total Fenol, dan Kadar Flavonoid Minuman Fungsional Sari Jagung-Ekstrak Bekatul," J. Pangan dan Agroindustri, vol. 6, no. 1, pp. 53-63, 2018, doi: 10.21776/ub.jpa.2018.006.01.7.

[28] N. N. F. Hanin and R. Pratiwi, "Kandungan Fenolik, Flavonoid dan Aktivitas Antioksidan Ekstrak Daun Paku Laut (Acrostichum aureum L.) Fertil dan Steril di Kawasan Mangrove Kulon Progo, Yogyakarta," J. Trop. Biodivers. Biotechnol., vol. 2, no. 1, pp. 51-56, 2017, doi: 10.22146/jtbb.29819.

[29] Amelia R .F., "Penetuan jenis tanin dan penetapan kadar tanin dari buah bungur muda (Lagerstroemia speciosa pers.) secara spektrofotometri dan perngamanometri.," J. Ilm. Mhs. Univ. surabaya, vol. 4, no. 2, pp. 1-20, 2015. 